\title{
The Prevalence and Subtype Distribution of Hepatitis C Virus Infection among Hemodialysis Patients in a Private Hospital in Surabaya, Indonesia
}

\author{
MOCHAMAD AMIN ${ }^{1,6}$, JUNIASTUTI $^{1,2,6}$, TAKAKO UTSUMI $^{6,7}$, YOSHIHIKO YANO $^{7}$, \\ MOCHAMAD YUSUF ${ }^{1,4}$, MOCHAMMAD THAHA $^{1,5}$, PRIYO BUDI PURWONO ${ }^{1,2,6}$, \\ RETNO HANDAJANI ${ }^{1,3}$, SOETJIPTO ${ }^{1,3,6}$, HAK HOTTA ${ }^{7}$, \\ YOSHITAKE HAYASHI ${ }^{7}$, AND MARIA INGE LUSIDA ${ }^{1,2,6 *}$
}

\author{
${ }^{1}$ Institute of Tropical Disease, Universitas Airlangga, Jalan Mulyoreijo, Surabaya 60115, Indonesia; \\ ${ }^{2}$ Department of Microbiology; ${ }^{3}$ Department of Biochemistry; ${ }^{4}$ Department of Cardiology; ${ }^{5}$ Department of Internal \\ Medicine, Faculty of Medicine, Universitas Airlangga, Jalan Mayjen Prof Dr Moestopo 47, \\ Surabaya 60131, Indonesia; \\ ${ }^{6}$ Indonesia-Japan Collaborative Research Center for Emerging and Re-emerging Infectious Diseases, \\ Universitas Airlangga, Jalan Mulyoreijo, Surabaya 60115, Indonesia; \\ Center for Infectious Diseases, Kobe University Graduate School of Medicine, Hyogo 650-0017, Japan
}

The prevalence of hepatitis $\mathrm{C}$ virus (HCV) infection has been as high as approximately $80 \%$ in patients with maintenance hemodialysis in public hospitals in Indonesia. However, the prevalence in private hospitals has not been examined yet. The aim of this study was to investigate the prevalence of anti-HCV antibody and the subtype distribution in patients with hemodialysis in a private hospital in Surabaya, Indonesia. Sera were obtained from 41 hemodialysis patients in a private hospital in Surabaya. The positive prevalence of anti-HCV antibody was carried out by the enzyme-linked immunosorbent assay (ELISA). Anti-HCV-positive sera were subjected to reverse transcription-PCR (RT-PCR) to detect HCV RNA and then direct sequencing. The HCV subtype was examined by phylogenetic analysis. Twenty five patients $(61 \%)$ out of 41 were positive for anti-HCV antibody, and HCV-RNA was detected in 19 patients. The positive prevalence of anti-HCV antibody was 7.7\% (one out of 13 patients) among patients who had undergone hemodialysis for less than one year, whereas it was $85.7 \%$ ( 24 out of 28 patients) among patients who had undergone hemodialysis for over one year. Phylogenetic analysis revealed HCV-1a (52.6\%) was the most common subtype, followed by $1 \mathrm{~b}(15.8 \%), 1 \mathrm{c}(15.8 \%), 2 \mathrm{a}(5.3 \%)$, and $3 \mathrm{k}$ $(5.3 \%)$. In conclusion, the prevalence of $\mathrm{HCV}$ infection among hemodialysis patients in a private hospital was as high as that in general hospitals. The predominant subtype was HCV-1a, which is in accordance with the previous studies in general hospitals in Surabaya, Indonesia.

Key words: anti-HCV, hepatitis C virus, hemodialysis, subtypes, Surabaya

Prevalensi infeksi virus hepatitis C (HCV) diperkirakan 80\% pada pasien dengan perawatan hemodialisis di rumah sakit umum di Indonesia. Akan tetapi, prevalensi di rumah sakit swasta belum diketahui. Tujuan dari penelitian ini adalah untuk mengetahui prevalensi antibodi anti-HCV dan distribusi subtipenya pada pasien dengan hemodialisis di sebuah rumah sakit swasta di Surabaya, Indonesia. Serum diperoleh dari 41 orang pasien hemodialisis di sebuah rumah sakit swasta di Surabaya. Deteksi prevalensi antibodi anti-HCV dilakukan dengan metode ELISA. Reverse-transcription-PCR (RT-PCR) dilakukan dengan menggunakan serum Anti-HCVpositif untuk mendeteksi HCV RNA, lalu disekuensing. Subtipe HCV dianalisa dengan menggunakan pohon kekerabatan. Dua puluh lima pasien $(61 \%)$ dari 41 diketahui positif memiliki antibodi anti-HCV, dan HCV-RNA terdeteksi pada 19 pasien. Prevalensi positif antibodi anti-HCV adalah 7,7\% (satu dari 13 pasien) di antara pasien yang telah menjalani hemodialisis selama kurang dari satu tahun, sedangkan itu 85,7\% (24 dari 28 pasien) di antara pasien yang telah menjalani hemodialisis selama lebih dari satu tahun. Analisa pohon kekerabatan mengungkapkan HCV-1a adalah subtipe yang paling umum sebanyak 52,6\%, diikuti oleh $1 \mathrm{~b}(15,8 \%), 1 \mathrm{c}$ $(15,8 \%), 2 \mathrm{a}(5,3 \%)$, dan 3k (5,3\%). Sebagai kesimpulan, prevalensi infeksi HCV di antara pasien hemodialisis di rumah sakit swasta adalah sama tinggi dengan yang di rumah sakit umum. Subtipe dominan adalah HCV-1a, yang juga sesuai dengan studi sebelumnya di rumah sakit umum di Surabaya, Indonesia.

Kata kunci: anti-HVC, hemodialisis, hepatitis C virus, subtipe, Surabaya

The Hepatitis C virus (HCV) has been proven to be a major etiologic agent of parentally transmitted virus. HCV has become a major cause of liver cancer and is one of the commonest indications for liver

*Corresponding author; Phone: +62-31-5992446. Fax: +6231-5992445,E-mail:ingelusida@yahoo.com transplantation (Francois et al. 1993; Pawlotsky et al. 2003; Ghany et al. 2009). WHO estimated that approximately 170 million people were chronically infected with $\mathrm{HCV}$, which is around $3 \%$ of the world population (http://www.who.int/emc). In general, approximately $20 \%$ of chronically $\mathrm{HCV}$ infected 
patients progress to liver cirrhosis over a period of 20 to 30 years, with hepatocellular carcinoma (HCC) arising from cirrhosis at an estimated rate of $1 \%$ to $4 \%$ per year (Lusida et al. 2000; Lavanchy et al. 2009).

It was reported from Surabaya that the prevalence of $\mathrm{HCV}$ infection was $2.3 \%$ of healthy blood donors, $64.7 \%$ of hepatocellular carcinoma and $76.3 \%$ of hemodialysis patients (Soetjipto et al. 1996). Transmission through medical procedures, such as blood transfusions and hemodialysis, is highly prevalent in developing countries. The prevalence of $\mathrm{HCV}$ among hemodialysis patients was variable, from 1.9 to $84.6 \%$ in different countries in recent years (Fissell et al. 2004; Alavian et al. 2010; Mohammad et al. 2010). The prevalence of HCV infection is much higher in developing countries as compared to developed countries. Previous studies from developing countries reported that the transmission of HCV among hemodialysis patients was generally nosocomial, and the possible risk factors were as follows: the failure to disinfect equipment between patients, the sharing of single-use vials for infusions, poor sterilization techniques, poor cleaning of dialysis machines, and inadequate distance between chairs (Zampieron et al. 2004; Theodore et al. 2006).

Several studies on hemodialysis patients showed that the prevalence of anti-HCV antibody positive was high in general hospitals in Surabaya, but the prevalence in private hospitals, which were generally considered to have a better standard of operation, has not been reported yet (Soetjipto et al. 1996; Lusida et al.2003; Santoso et al. 2010).

The aims of this study were to determine the seropositive prevalence of anti-HCV antibody and the distribution of HCV subtypes in hemodialysis patients in a private hospital in Surabaya.

\section{MATERIALS AND METHODS}

Hemodialysis Unit, Sample Collections and Serological Analysis for Anti-HCV Antibody. Sera were collected from 41 hemodialysis patients (mean age $43.9 \pm 11.8$ years, 28 male, 13 female) in a private hospital in Surabaya from January to June 2011. Collected samples were stored at $-80^{\circ} \mathrm{C}$ in a freezer in the hepatitis laboratory, Institute of Tropical Disease, Airlangga University, Surabaya, Indonesia. The anti$\mathrm{HCV}$ antibody was serologically examined using enzyme-linked immunosorbent assay (ELISA) kit (Hepalisa, Indec, Jakarta, Indonesia). Limited data was available regarding the risk factors associated with
$\mathrm{HCV}$ infection. Separate rooms were not available for patients seropositive for anti-HCV.

Polymerase Chain Reaction and Direct Sequencing for HCV-RNA. Following this, HCVRNA was examined by reverse transcriptionpolymerase chain reaction (RT-PCR) among anti-HCV antibody positive samples, as described previously (Doi et al. 1996; Soetjipto et al. 1996; Murphy et al. 2007). At first, RT-PCR was carried out using different sets of primers in NS5B region. The amplification in 5 'UTR region was then carried out by RT-PCR in case of negative for NS5B region (Hotta et al. 1994; Doi et al. 1996; Soetjipto et al. 1996; Murphy et al. 2007). These methods have been shown to be highly sensitive for the detection of HCV RNA in anti-HCVpositive sera from patients with chronic liver disease in Japan and Indonesia (Soetjipto et al. 1996). The PCR products were visualized on $2 \%$ agarose gel with ethidium bromide. Isolation and purification of the PCR product used QIAquick PCR Purification Kit (Qiagen GmbH, Hilden, Germany). Nucleotide sequences of the amplified fragments were determined with the BigDye V1.1 Terminator Cycle Sequencing kit and ABI Prism 310 Genetic Analyzer (Applied Biosystems, USA).

Determination of HCV Subtype. The genotype and subtype of HCV nucleotide sequences of the specimens were compared with those of the international DNA data bank (DDBJ/EMBL/GeneBank) to determine HCV subtypes by following the criteria (Simmonds et al. 2005). A phylogenetic tree was reconstructed by the Unweighted Pair Group Method using Arithmetic averages (UPGMA) method using clustering in Genetyx for Windows Version 9.0.

\section{RESULTS}

Seropositive Prevalence for anti-HCV antibody. Among 41 hemodialysis patients, 25 patients (61\%) (18 men and 7 women, aged 21 to 64 years) were positive for anti-HCV antibody. The positive prevalence of anti-HCV antibody was $7.7 \%$ (one out of 13 patients) among patients who underwent hemodialysis for less than one year, whereas it was $85.7 \%$ (24 out of 28 patients) among patients who underwent hemodialysis for more than one year.

Detection of HCV-RNA and Determination of Genotype and Subtype. HCV-RNA in NS5B region was detected in 18 out of 25 hemodialysis patients with anti-HCV antibody positive. Phylogenetic analysis revealed HCV-1a $(n=10)$ was the most common 
subtype, followed by $1 \mathrm{~b}(\mathrm{n}=3), 1 \mathrm{c}(\mathrm{n}=3), 2 \mathrm{a}(\mathrm{n}=1)$, and $3 \mathrm{k}(\mathrm{n}=1)$ (Fig 1). Among HCV-1a isolates, the homology was more than $95 \%$ of 294 bp (data were not shown). HCV-RNA in 5'UTR region was also examined and confirmed the positive prevalence of HCV-RNA. Only one sample (HD50) detected HCVRNA based on 5'UTR region among those negative samples based on NS5B region. In the multiple alignments, this amplified fragment of 5'UTR showed similarities of nucleotide sequences with genotype 1 , both in motifl and motif2 (Fig 2). In total, 19 (76\%) out of 25 hemodialysis patients with anti-HCV antibody positive were positive for HCV-RNA. The number of genotypes and subtypes are summarized in Fig 3.

\section{DISCUSSION}

It was reported that the anti-HCV antibody seropositive prevalence among hemodialysis patients in the general hospital was $73.5 \%$ in 2003 , from a study in West Java, Indonesia and 81\% in 2013, from a study in Central Java, Indonesia (Saketi 2003 and Rinonce 2013, respectively). The high prevalence of $\mathrm{HCV}$ infection is associated with the combination of

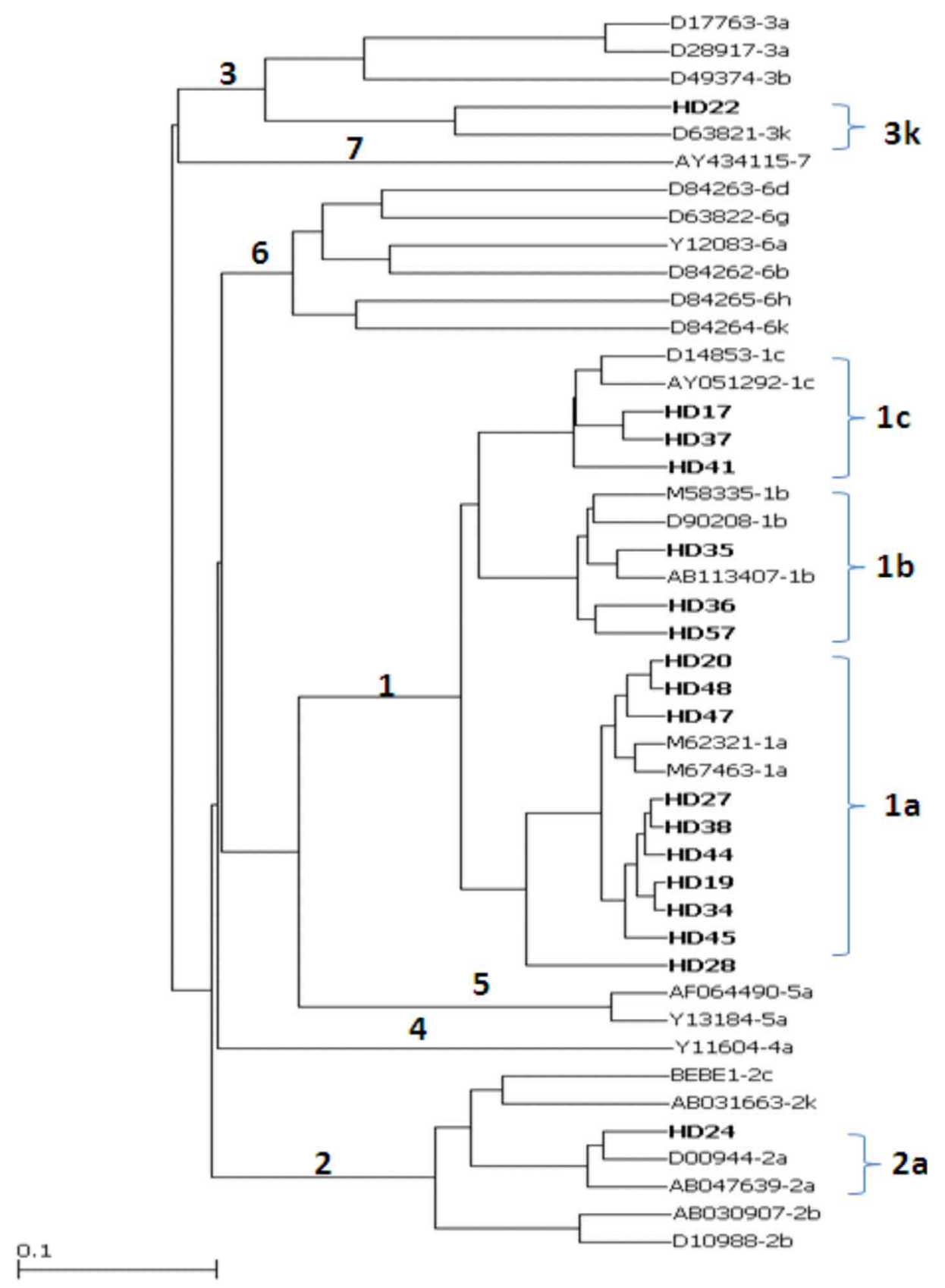

Fig 1 Phylogenetic analysis based on NS5B sequences (294bp). Collected samples in present study (printed in bold) were aligned with strains from the DNA data bank (DDBJ). The genotypes were written in the roof of the branch and subtypes were indicated in the right side. Bar, 10 substitution per 100 nucleotides. 
Motif 1

Motif 2

HD 50 TACACCGG AAT TGCCAGGACGACCGGGTCCT TT C_- TTGGAT C-AACC CGCTCAA TGCCTGGAGAT TTGGGCG TGCCCCC

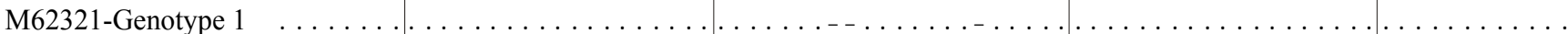
AB047639-Genotype 2 D63821-Genotype 3 Y11604-Genotype 4 Y13184-Genotype 5 Y12083-Genotype 6

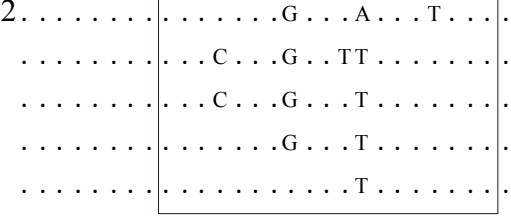

Fig 2 Determination of genotype based on 5'UTR region. HCV-RNA in one sample (HD50) was negative for HCV-RNA by NS5B region but positive for 5'UTR region. The genotyping was determined based on Motif 1 and 2 in the 5'UTR region.

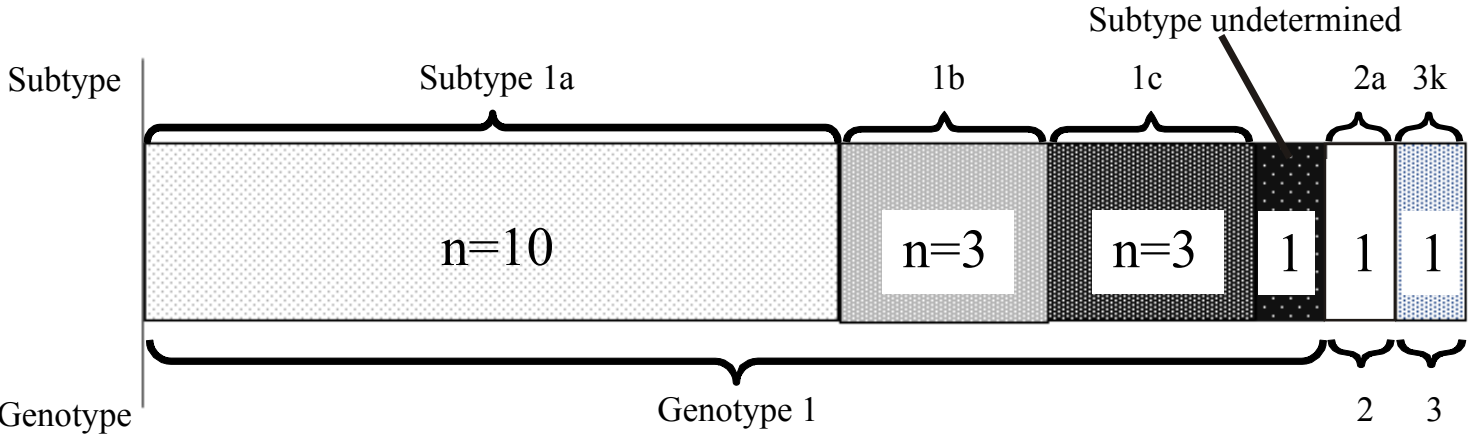

Fig 3 Summary of genotype and subtype in hemodialysis patients in this study. Subtypes $(n=18)$ were determined by NS5B region and genotypes were determined by NS5B and 5'UTR region.

frequent blood transfusions and the lack of adherence to universal infection precautions (Santoso et al. 2010). Present studies revealed that the HCV prevalence among hemodialysis patients in this private hospital was $61 \%$ and which was in accordance with our previous study in the general hospital (Soetjipto et al. 1996; Lusida et al. 2003). These results suggested that $\mathrm{HCV}$ infection among hemodialysis patients was still highly prevalent in Surabaya, East Java.

$\mathrm{HCV}$ has been classified as the sole member of a distinct genus called Hepacivirus in the family Flaviviridae. The HCV genome carries a single long open reading frame (ORF) encoding a polyprotein that is proteolytically cleaved into a set of distinct products. Analysis of the HCV genome has revealed the high heterogeneity of the virus. In humans, at least seven different genotypes have been classified based on the relatively well-conserved regions of the genome (5'UTR, C, E1, NS5B or complete genome) (Doi et al. 1996; Bartenschlager et al. 2000; Simmond et al. 2005; Utama et al. 2009). Epidemiological studies also show a link of a certain HCV genotype with the mode of transmission and geographic distribution (Simonds et al. 2005). Genotypes 1 to 3 were detected globally, while genotype 4 was common in the Middle East and Africa (Bukh et al. 1993; Abdel-Hamid et al. 2007), genotypes 5 and 6 were found in South Africa (Smuts et al. 1995) and Southeast Asia (Lu et al. 2007) and genotype 7 were found in Central Africa (Murphy et al. 2007).

The present study revealed that several subtypes, including subtype 1a, 1b, 1c, 2a, and 3k, were found in hemodialysis patients. A previous study revealed that subtype $2 \mathrm{a}(52 \%)$ and $1 \mathrm{~b}(15 \%)$ were prevalent among healthy blood donors from Surabaya, Indonesia (Soetjipto et al. 1996). Recent studies have revealed that subtypes $1 \mathrm{~b}(47 \%)$ and $1 \mathrm{c}(19 \%)$ were prevalent among HCV-related liver diseases in Jakarta, Indonesia, and subtypes $1 \mathrm{a}(52 \%)$ and $3 \mathrm{k}(16 \%)$ were prevalent among $\mathrm{HCV}$ and human immunodeficiency virus (HIV) co-infected patients from Yogyakarta, Indonesia (Utama et al. 2010; Anggorowati et al. 2012). The genetic diversity differs depending on the geographic and clinical distributions. Previous studies from Surabaya and Yogyakarta revealed that 1a was dominant among hemodialysis patients in the general hospitals (Hadiwandowo et al. 1994; Soetjipto et al. 1996; Rinonce et al. 2013). Present study also found that subtype 1a was the most prevalent among hemodialysis patients. It has still not been determined why 1a was predominant in hemodialysis patients in Indonesia, while subtype $1 \mathrm{~b}$ was the most prevalent among HCV-related liver diseases in Jakarta and Surabaya (Hotta et al. 1994; Soetjipto et al. 1996; Utama et al. 2010). On the other hand, frequent exposure to $\mathrm{HCV}$-contaminated blood may favor the 
emergence of mixed genotype infection. Subtype 1a might be easily transmitted among hemodialysis patients through the adaption of impaired immunity. When mixed-genotype infection involving $\mathrm{HCV} / 1 \mathrm{a}$ occurs, this subtype tends to prevail and persists as the only subtype during the course of the disease (Qian et al. 2000).

The possible sources of the high prevalence of $\mathrm{HCV}$ infection are blood transfusion and nosocomial infection in the hemodialysis unit. A recent study from Yogyakarta also revealed the possibility of nosocomial infection based on the molecular analysis of HCV genome among patients using the same hemodialysis unit (Rinonce et al. 2013). The present study also revealed that HCV genome of 5'UTR and NS5B regions among patients of the same HCV subtype mostly showed high homology with each other and this was suggested to be nosocomial infection. The sequence homology among $\mathrm{HCV}$ isolates of the same subtype was quite high (more than $95 \%$ for $\mathrm{HCV}-1 \mathrm{a}$ ), even though it was not $100 \%$, because of the nature of quasispecies of HCV.

The most important factor of HCV transmission in the hemodialysis unit is considered to be a crosscontamination from supplies and unit staff (Fabrizi et al. 2008). It was reported from Yogyakarta that HCV infection was independently associated with hemodialysis frequency and the number of blood transfusions (Rinonce et al. 2013). According to the current concept, dialyzer reuse was not identified as a risk factor for $\mathrm{HCV}$ acquisition in multicenter databases and no randomized controlled trials existed on the impact of isolation on the risk of transmission of $\mathrm{HCV}$ to hemodialysis patients (Fabrizi et al.2008). Compared to our previous study in 1996 (Soetjipto et al. 1996), this study also shows that there is no improvement in the $\mathrm{HCV}$ infection control in hemodialysis units in Indonesia. The nosocomial infection is still common in developing countries and a strict policy for infection control, including separate dialysis machines, is recommended to prevent the $\mathrm{HCV}$ spreading. A study from India reported that HCV seroconversion was significantly improved from $36.2 \%$ to $2.75 \%$ by using the isolation room for $\mathrm{HCV}$ infected patients (Agarwal et al. 2009). A study from Saudi Arabia also demonstrated that dedicated space and the improvement in sharing the usage of dialysis equipment, as well as education for unit staff, were effective in reducing the annual seroconversion rate from $6.8 \%$ to $1.0 \%$ (Saxena et al. 2003 ).

In conclusion, the prevalence and predominant subtype of HCV infection in hemodialysis patients in a private hospital was similar as that in general hospitals in Surabaya. Further investigation in other private hospitals with different levels of quality will be necessary to evaluate the $\mathrm{HCV}$ infection among hemodialysis patients in Indonesia. Both routine precautions and education of the unit staff will be necessary to reduce the viral transmission in the hemodialysis unit.

\section{ACKNOWLEDGMENT}

We wish to thank Nasronudin of the Institute of Tropical Disease (ITD)-Universitas Airlangga, Surabaya, Indonesia for his cooperation and $\mathrm{M}$. Soetomo of the Al Irsyad Hospital, Surabaya, Indonesia, for the collection of samples from the hemodialysis department of Al Irsyad Hospital. This study was supported in part by a Grant-in-Aid from the Japan Initiative for Global Research Network on Infectious Diseases (J-GRID) program from Ministry of Education, Culture, Sports, Science, and Technology, Japan.

\section{REFERENCES}

Abdel-Hamid M, El-Daly M, Molnegren V, El-Kafrawy S, Abdel-Latif S, Esmat G, Strickland GT, Loffredo C, Albert J, Widell A. 2007. Genetic diversity in hepatitis $\mathrm{C}$ virus in Egypt and possible association with hepatocellular carcinoma. J Gen Virol. 88(5): 15261531. doi: 10.1099/vir.0.82626-0.

Agarwal SK, Dash SC, Gupta S, Pandey RM. 2009. Hepatitis $C$ virus infection in haemodialysis: the 'noisolation' policy should not be generalized. Nephron Clin Pract. 111:c133-140. doi: 10.1159/000191208.

Alavian SM. 2010. Hepatitis C in hemodialysis patients needs more attention for control and review the risk factors. Saudi J Kidney Dis Transpl. 21(2): 357-358.

Anggorowati N, Yano Y, Heriyanto DS, Rinonce HT, Utsumi T, Deshinta PM, Subronto YW, Hayashi Y. 2012. Clinical and virological characteristics of hepatitis B or $\mathrm{C}$ virus co-infection with HIV in Indonesian patients. $\mathrm{J}$ Med Virol. 84(6): 857-865. doi: 10.1002/jmv.23293.

Bartenschlager R, Lohmann V. 2000. Replication of hepatitis C virus. Review Article. J Gen Virol. 81:1631-1648.

Bukh J, Purcell RH, Miller RH. 1993. At least 12 genotypes of hepatitis $\mathrm{C}$ virus predicted by sequence analysis of the putative $\mathrm{E} 1$ gene of isolates collected worldwide. Proc Natl Acad Sci USA. 90(17): 8234-8238. doi: 10.1073/pnas.90.17.8234.

Doi H, Apichartpiyakul C, Ohba KI, Mizokami M, Hotta H. 1996. Hepatitis C Virus (HCV) Subtype Prevalence In Chiang Mai, Thailand, and Identification of Novel Subtypes Of HCV Major Type 6. J Clin Microbiol. 
34(3): 569-574

Fabrizi F, Messa P, Martin P. 2008. Transmission of hepatitis $C$ virus infection in hemodialysis: current concepts. Int JArtif Organs. 31(12): 1004-1016.

Francois M, Dubois F, Brand D, Bacq Y, Guerois C, Mouchet C, Tichet J, Goudeau A, Barin F. 1993. Prevalence and significance of hepatitis $\mathrm{C}$ virus (HCV) viremia in $\mathrm{HCV}$ antibody-positive subjects from various populations. $\mathrm{J}$ Clin Microbiol. 31(5): 1189-1193.

Fissell RB, Bragg-Gresham JL, Woods JD, Jadoul M, Gillespie B, Hedderwick SA, Rayner HC, Greenwood RN, Akibat T, Young EW. 2004. Patterns of hepatitis C prevalence and seroconversion in hemodialysis units from three continents: The DOPPS. Kidney International 65:2335-2342. doi:10.1111/j.15231755.2004.00649.x.

Ghany MG, Strader DB, Thomas DL, Seeff LB. 2009. Diagnosis, management, and treatment of hepatitis $\mathrm{C}$ : an update. Hepatology 49(4):1335-1374. doi: 10.1002/hep. 22759.

Hadiwandowo S, Tsuda F, Okamoto H, Tokita H, Wang Y, Tanaka T, Miyakawa Y, Mayumi M. 1994. Hepatitis B virus subtypes and hepatitis $\mathrm{C}$ virus genotypes in patients with chronic liver disease or on maintenance hemodialysis in Indonesia. J Med Virol. 43(2):182-186. doi: 10.1002/jmv.1890430216.

Hotta H, Handajani R, Lusida MI, Soemarto W, Doi H, Miyajima H, Homma M. 1994. Subtype analysis of hepatitis $\mathrm{C}$ virus in Indonesia on the basis of NS5B region sequences. J Clin Microbiol. 32(12): 3049-3051.

Lavanchy D. 2009. The global burden of hepatitis C. Liver International 29(s1):74-81. doi:10.1111/j.14783231.2008.01934.x

Lu L, Li C, Fu Y, Thaikruea L, Thongswat S, Maneekarn N, Apichartpiyakul C, Hotta H, Okamoto H, Netski D, Pybus OG, Murphy D, Hagedorn CH, Nelson E. 2007. Complete genome for hepatitis $\mathrm{C}$ virus subtypes $6 \mathrm{f}, 6 \mathrm{i}$, $6 \mathrm{j}$ and $6 \mathrm{~m}$ : viral genetic diversity among Thai blood donors and infected spouses. J Gen Virol. 88(5): 1505 1518. doi: 10.1099/vir.0.82604-0.

Lusida MI, Soetjipto, Handajani R, Nidom CA, Soemarto, Darmadi S, Adi P, Fujii MN, Fujita T, Ishido S, Hotta H. 2000. Viral load in indonesian patients with chronic liver disease and in blood donors infected with different subtypes of hepatitis C Virus. Jpn J Infect Dis. 53(2): 67-69.

Lusida MI, Surayah, Sakugawa H, Nagano-Fujii M, Soetjipto, Mulyanto, Handajani R, Boediwarsono, Setiawan PB, Nidom CA, Ohgimoto S, Hotta H. 2003. Genotype and subtype analyses of hepatitis B virus (HBV) and possible co-infection of HBV and hepatitis $\mathrm{C}$ virus (HCV) or hepatitis D virus (HDV) in blood donors, patients with chronic liver disease and patients on hemodialysis in Surabaya, Indonesia. Microbiol Immunol. 47(12): 969-975.

Mohammad WZ. 2010. Prevalence of Hepatitis C virus in hemodialysis patients: Five year experience from a single center. Saudi J Kidney Dis Transpl. 21: 548-554.

Murphy DG, Willems B, Deschênes M, Hilzenrat N,
Mousseau R, Sabbah S. 2007. Use of sequence analysis of the NS5B region for routine genotyping of hepatitis $\mathrm{C}$ virus with reference to $\mathrm{C} / \mathrm{E} 1$ and $5^{\prime}$ untranslated region sequences. J Clin Microbiol. 45(4): 1102-1112. doi: 10.1128/JCM.02366-06.

Pawlotsky JM. 2003. Use and interpretation of hepatitis C virus diagnostic assays. Clin Liver Dis. 7(1): 127-137. doi: 10.1016/S1089-3261(02)00064-8.

Qian KP, Natov SN, Pereira BJ, Lau JY. 2000. Hepatitis C virus mixed genotype infection in patients on haemodialysis. J Viral Hepat. 7(2):153-160. doi: 10.1046/j.1365-2893.2000.00208.x.

Rinonce HT, Yano Y, Utsumi T, Heriyanto DS, Anggorowati N, Widasari DI, Lusida MI, Soetjipto, Prasanto H, Hotta H, Hayashi Y. 2013. Hepatitis B and C virus infection among hemodialysis patients in Yogyakarta, Indonesia: Prevalence and molecular evidence for nosocomial transmission. J Med Virol In press.

Saketi JR, Boland GJ, van Loon AM, van Hattum J, Abdurachman SA, Sukandar E. 2003. Prevalence of hepatitis $\mathrm{C}$ virus infection among haemodialysis patients in West Java, Indonesia. Adv Exp Med Biol. 531:201-209. doi: 10.1007/978-1-4615-0059-9 16.

Santoso D, Pranawa, Yogiantoro M, Widodo, Wardana A, Mardiana N, Irwanadi C, Soewanto, Shou I, Maeda K, Hamada C, Fukui M, Horikoshi S, Tomino Y. 2010. Hepatitis $\mathrm{C}$ virus infection in hemodialysis patients: Comparison of the Surabaya dialysis center and Juntendo University Hospital Dialysis center. Indonesian J Trop and Infect Dis. 1(3): 105-109.

Saxena AK, Panhotra BR, Sundaram DS, , Venkateshappa CK, Uzzaman W, Mulhim KA. 2003. Impact of dedicated space, dialysis equipment, and nursing staff on the transmission of hepatitis $\mathrm{C}$ virus in a hemodialysis unit of the middle east. Am J Infect Control. 31(1): 26-33. doi: 10.1067/mic.2003.55.

Simmonds P, Bukh J, Combet C, Del'eage G, Enomoto N, Feinstone S, Halfon P, Inchausp'e G, Kuiken C, Maertens G, Mizokami M, Murphy DG, Okamoto H, Pawlotsky JM, Penin F, Sablon E, Shin-I T, Stuyver L.J, Thiel H, Viazov S, Weiner AJ, and Widell A. 2005. Consensus proposals for a uni ed system of nomenclature of hepatitis $\mathrm{C}$ virus genotypes. Hepatology 42(4): 962-973. doi: 10.1002/hep.20819.

Smuts HE, Kannemeyer J. 1995. Genotyping of hepatitis C virus in South Africa. J Clin Microbiol. 33(6): 16791681.

Soetjipto, Handajani R, Lusida MI, Darmadi S, Adi P, Soemarto, Ishido S, Katayama Y, Hotta H. 1996. Differential prevalence of hepatitis $\mathrm{C}$ virus subtypes in healthy blood donors, patients on maintenance hemodialysis, and patients with hepatocelluler carcinoma in Surabaya, Indonesia. J Clin Microbiol. 34(12): 2875-2880.

Theodore SY, Jamal M. 2006. Epidemiology of hepatitis C Virus (HCV) Infection. Int J Med Sci. 3(2): 41-46.

Utama A, Budiarto BR, Monasari D, Octavia TI, Chandra IS, Gani RA, Hasan I, Sanityoso A, Miskad UA, Yusuf I, Lesmana LA, Sulaiman A; Tai S. 2008. Hepatitis C virus genotype in blood donors and associated liver 
disease in Indonesia. Intervirology 51(6): 410-416. doi: $10.1159 / 000205515$

Zampieron A, Jayasekera H, Elseviers M, Lindley E, De Vos JY, Visser R, Harrington M. 2004. European study on epidemiology and the management of HCV in the haemodialysis population, Part 1: Centre Policy. EDTNA ERCA J. 30(2): 84-90. doi: 10.1111/j.17556686.2004.tb00341.x. 